\title{
Schistosomiasis in Lake Malawii and the Potential Use of Indigenous Fish for Biological Control
}

\author{
Jay R. Stauffer, Jr. ${ }^{1}$ and Henry Madsen ${ }^{2}$ \\ ${ }^{1}$ School of Forest Resources, Penn State University, University Park, PA \\ ${ }^{2} \mathrm{DBL}$ Centre for Health Research and Development, \\ Faculty of Life Sciences, University of Copenhagen, Frederiksberg \\ 1 USA \\ ${ }^{2}$ Denmark
}

\section{Introduction}

Schistosomiasis is a parasitic disease of major public health importance in many countries in Africa, Asia, and South America, with an estimated 200 million people infected worldwide (World Health Organization, 2002). The disease is caused by trematodes of the genus Schistosoma that require specific freshwater snail species to complete their life cycles (Fig. 1). People contract schistosomiasis when they come in contact with water containing the infective larval stage (cercariae) of the trematode.

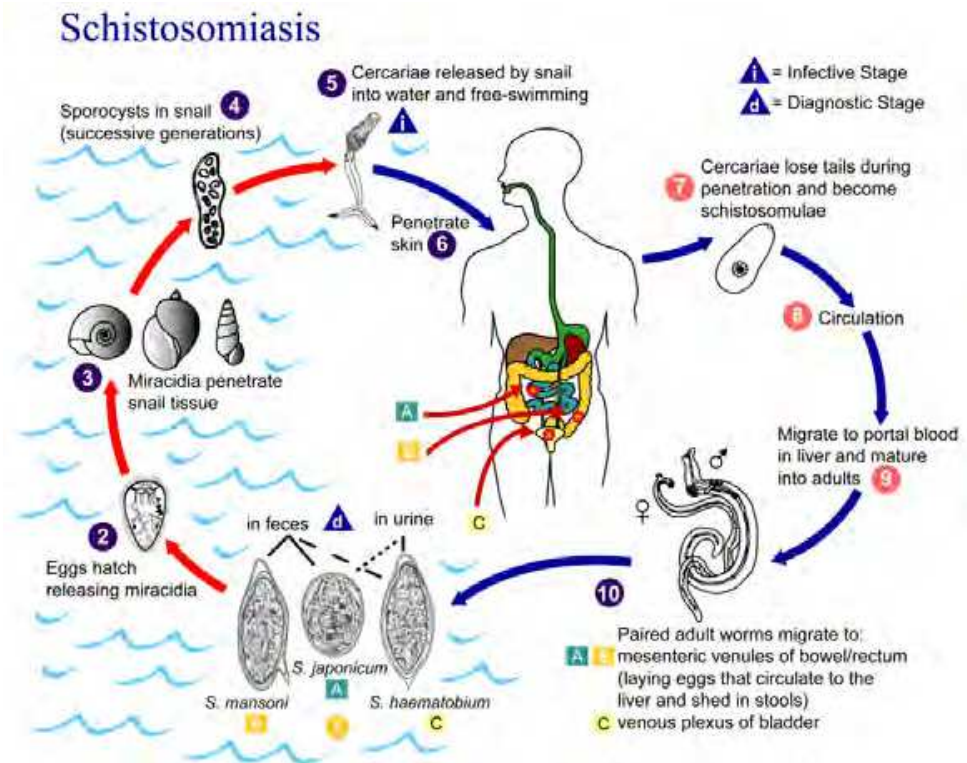

Fig. 1. Life cycle of schistosomes (Source: CDC/Alexander J. da Silva, PhD/Melanie Moser) 
Schistosome transmission, Schistosoma haematobium, is a major public health concern in the Cape Maclear area of Lake Malaŵi (Fig. 2), because the disease poses a great problem for local people and reduces revenue from tourism. Until the mid-1980's, the open shores of Lake Malawi were considered free from human schistosomes (Evans, 1975; Stauffer et al., 1997); thus, only within relatively protected areas of the lake or tributaries would transmission take place. These areas were suitable habitat of intermediate host snail, Bulinus globosus. During mid-1980's, reports indicated that transmission also occurred along open shorelines. It is now evident that in the southern part of the lake, especially Cape Maclear on Nankumba Peninsula, transmission occurs along exposed shorelines with sandy sediment devoid of aquatic plants via another intermediate host, Bulinus nyassanus (Madsen et al., 2001, 2004). This species is endemic to Lake Malawi i and is a diploid $(2 \mathrm{n}=36)$ member of the tropicus/truncatus group of Bulinus where also the most important hosts of $S$. haematobium in North Africa belong, i.e., B. truncatus $(4 \mathrm{n}=72)$. The changes in transmission pattern could be related in part to over-fishing which clearly has resulted in decline in density of several cichlid fish species (Stauffer et al., 1997), some of which are important predators of snails or a new strain of Schistosoma haematobium capable of exploiting B. nyassanus as host. Another diploid species of this group, Bulinus succinoides has not been shown to be a host. Stauffer et al. (1997) suggested that a lakewide strategy for controlling schistosome intermediate hosts using fishes should be initiated to reduce the prevalence of this disease. Preliminary studies indicated that the facultative molluscivore and popular food fish, Trematocranus placodon, is effective at controlling schistosome intermediate host snails in fishponds (Chiotha et al., 1991a, b).

Although all types of fishing are prohibited within a 100-m zone along the shoreline within Lake Malawi i National Park, this clearly is not respected. Seine-net fishing from the shoreline is often observed and gill-nets are often found within this sanctuary zone (pers. obs.). Beach seining, however, is the most damaging form of fishing, since nets are often very fine meshed (sometimes lined with mosquito nets) and since the near-shore zone of the lake is where juvenile fishes reside; thus, recruitment of fish populations is seriously affected. It is evident that densities of some cichlid species, including molluscivorous species, have declined markedly in shallow waters compared to densities during the early 1980s (Stauffer et al., 2006). Here we summarize the results of a six year study of the interactions among fish abundance, snail intermediate hosts for Schistosoma haematobium, and prevalence of human infections.

\section{Study area}

Lake Malawi (Fig. 2), the most southerly lake in the East African Rift Valley system, is over $600 \mathrm{~km}$ long (Beadle, 1974) and is $75 \mathrm{~km}$ wide at its widest point; its total surface area is approximately $29,600 \mathrm{~km}^{2}$. As such, it is the third largest lake in the world by volume and the ninth largest by surface area. The lake is bordered by western Mozambique, eastern Malawii, and Tanzania. Its largest tributary is the Ruhuhu River and its outlet is the Shire River, a tributary of the Zambezi. The largest part of the lake is in Malawi, while about a quarter of the lake area is under the jurisdiction of Mozambique; this includes the area surrounding the Malawiian islands of Likoma and Chizumulu, which are the lake's only two inhabited islands. It is bordered by Malawii, Mozambique, and Tanzania. It is also the second deepest lake in Africa. The lake harbors more fish species than any other lake on Earth. 


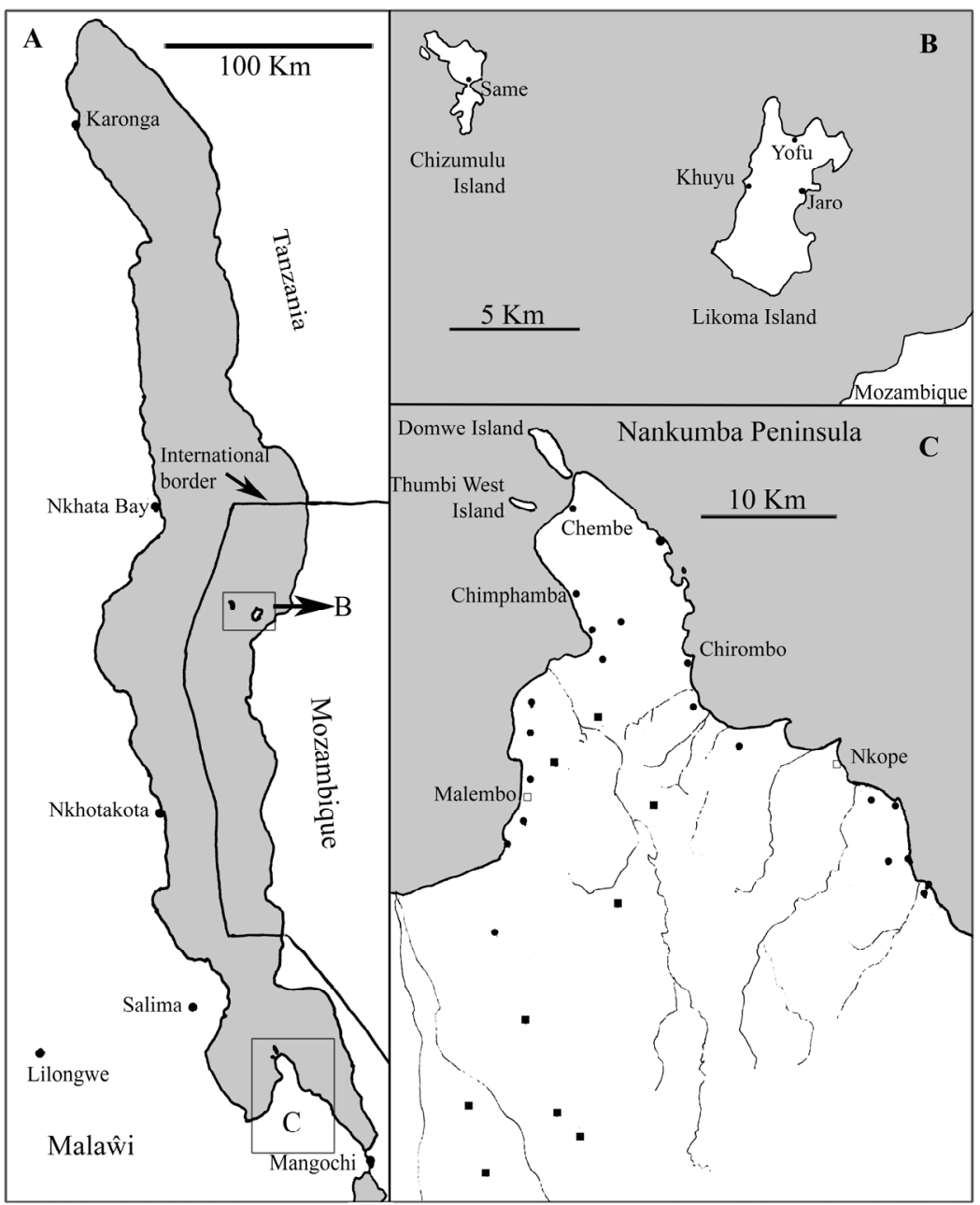

Fig. 2. Lake Malaŵi and some of our sampling sites (Source: Madsen et al. in press).

The climate is generally tropical with a rainy season from November to April. There is little to no rainfall throughout much of the country from May to October. It is hot and humid from September to April along the lake, with average daytime maxima of $27-29^{\circ} \mathrm{C}$. From June through August, the daytime maxima are around $23^{\circ} \mathrm{C}$. During the cold months the prevailing wind is southerly.

Fishes from Lake Malawi are the major food source to the residents of Malawi. The Malawians prefer chambo, which consists of any one of four species of the cichlid genus Oreochromis, as well as the kampango, a large catfish (Bagrus meridionalis).

The water in Lake Malawi is typically alkaline with a $\mathrm{pH}$ of 7.7-8.6, a carbonate hardness of $107-142 \mathrm{mg} \mathrm{l}^{-1}$ and a conductivity of $210-285 \mu \mathrm{Scm}-1$. The lake water is generally warm, having a surface temperature that ranges from $24-29^{\circ} \mathrm{C}$ and a deep level temperature of $22^{\circ} \mathrm{C}$. 
Lake Malawii National Park, a World Heritage site since 1984 and the World's first freshwater underwater park, is located on and around the Nankumba Peninsula. The park includes some islands, the separate Mwenya Hills, Nkhudzi Hills and Nkhudzi Point at the eastern base of the peninsula, and an aquatic zone extending $100 \mathrm{~m}$ offshore of all these areas. Its aim is to protect portions of Lake Malawit's aquatic communities so the steep hills immediately behind the shoreline are protected to prevent eroded sediments polluting the lake. A managed fishing zone is designated just offshore incorporating some islands within the park, but trawling is prohibited. Other fishing methods such as gill netting, long line, and trapping are prohibited within the $100 \mathrm{~m}$ aquatic zone of the reserve.

Much of the lakeshore is heavily populated. Five shoreline villages, Chembe, Chimphamba, Mvunguti, Zambo and Chidzale, are included within enclaves in the park. As the soil of the peninsula is poor and crops fail about $50 \%$ of the time, local people are dependent on fishing for a livelihood. Some 40,000 people make a living directly from the lake in offshore fisheries, providing most of the country's animal protein intake.

\subsection{Study sites}

In the following we will refer to specific villages and these are briefly described below. On Nankumba Peninsula, detailed studies were done in 4 villages, i.e. Chembe, Chimphamba, Mvunguti, and Chirombo Bay.

Chembe is a fishing village with a population of roughly $8,000-10,000$. Chembe (Fig. 3) is located on an open bay on the northern part of the Monkey Bay peninsula. It is well protected from the strong winds which blow in the southern and eastern sections of Lake

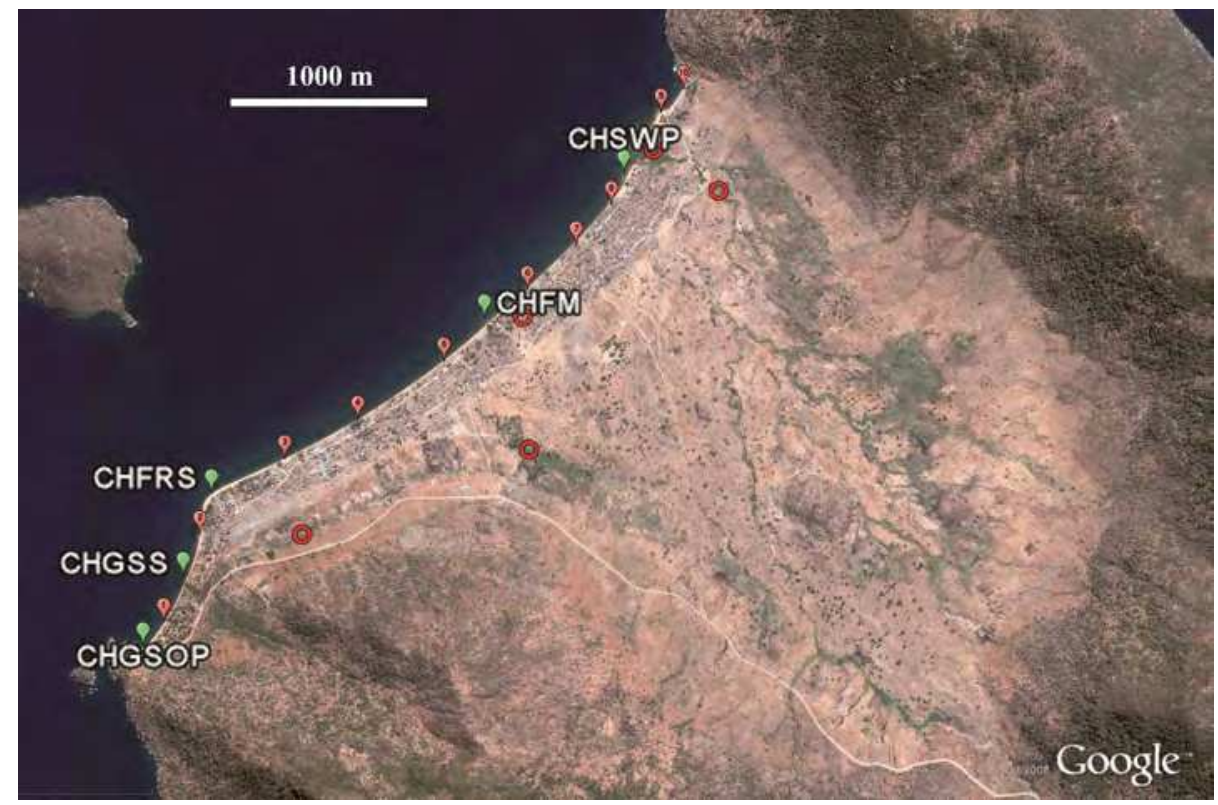

Fig. 3. Sampling sites in Chembe Village area. Green labeled symbols show transect sampling sites and red numbered symbols scooping sites. Red circles show inland sampling sites. 
Malawii. People live primarily along an approximately $3000 \mathrm{~m}$ stretch of shoreline to a distance of about $250-300 \mathrm{~m}$ from the shore. The shoreline is facing northwest and the inland area is rather low and traversed by a number of streams and rivers, which are potential habitats for Bulinus globosus, an intermediate host for the urinary schistosome, Schistosoma haematobium. In the upland areas, some agricultural activities take place.

Chimphamba, with a population of about 2000 people, is located along an approximately 1.2 $\mathrm{km}$ shoreline facing southwest. The village area is surrounded by mountains and a few short streams cross the village area. To the south, there is a valley with one major in-flowing stream. The lake bottom outside the village is heavily polluted with various debris.

Mvunguti is located along an approximately $400 \mathrm{~m}$ sandy shoreline facing north and the village area extending up to about $300 \mathrm{~m}$ from the shore is surrounded by mountains. At each end of the village a small stream flows through the village area. Both streams are habitats for B. globosus. The lake bottom slopes steeply.

Chirombo Bay is located along an approximately $1700 \mathrm{~m}$ stretch of sandy shoreline facing east. Most people live along the southernmost $1000 \mathrm{~m}$ of this shoreline. The upland is flat and the lake bottom slopes gently, so the maximum depth sampled within $200 \mathrm{~m}$ from the shoreline was $4.5 \mathrm{~m}$. Population density is not high. The upland areas contain a number of streams that can harbor B. globosus.

Kasankha is located along an approximately $1800 \mathrm{~m}$ stretch of sandy shoreline facing northwest. Houses are primarily found less than $400 \mathrm{~m}$ from the shoreline. The bottom slope is relatively gentle and the shoreline well protected. Close to the southern end of the beach, a river flows into the lake forming a swampy area, which is habitat for B. globosus. At the northern end of the beach, a small seasonal stream joins the lake. Crocodile and hippopotamuses are often seen in the bay and therefore this site was excluded from regular sampling. Bulinus nyassanus is abundant in the lake at this site.

Matola village is located along an open shoreline with gentle slope and the maximum depth that could be sampled within $200 \mathrm{~m}$ from shore was $4.5 \mathrm{~m}$. Bulinus nyassanus was often found at high densities in relatively shallow water, but inland sites were not checked at this location. Also, B. succinoides was generally abundant in Vallisneria beds.

Finally, a number of sites were sampled along the Malawian shoreline in the northern part of the lake and most of these sites had relatively exposed sandy shorelines and generally density of $B$. nyassanus was low. Often inland sites, however, are important habitats for $B$. globosus. Some of these sites were close to the shore and kept flooded from wave action in the lake. Two sites were selected on the islands, i.e. Same Bay on Chizumulu Island and Yofu on Likoma Island. Same Bay is a protected bay with a stretch of sandy beach and a large area with very shallow water with stones and/or grass. Within this area, rice is cultivated and the area contains a dense population of $B$. globosus. The lake outside the sandy beach harbors $B$. nyassanus at relatively low density. Yofu is located along a sandy beach which is quite exposed to wave action.

Along the Tanzanian coast the lake bottom slopes very steeply at most sites and is therefore unsuitable for Bulinus snails. Only at Liuli did we find B. nyassanus. In one pool next to the lake, we found Biomphalaria pfeifferi infected with Schistosoma mansoni.

\section{Schistosomiasis in people at Lake Malaŵi}

Malawi is one of the countries where both urinary and intestinal schistosomiasis is endemic (Teesdale et al. 1986); around the lake, however, the urinary form caused by S. haematobium 
is dominant. Although schistosomiasis has been a major public health problem for many years in many lakeshore communities of Lake Malawi $\mathrm{i}$, there is evidence that transmission has increased in certain areas within the last 20 years (Stauffer et al. 2006). In addition to causing a major health problem for local people, the disease also affects an important source of income for the country, namely tourism. The area around Cape Maclear is a World Heritage Site and is visited by many tourists every year. Unfortunately, many visitors become infected with schistosomes and some health organizations such the United States Centers for Disease Control and Prevention (CDC) warn against visiting Lake Malawi $i$ (Centers for Disease Control, 2005).

On Nankumba Peninsula, in the southern part of the lake overall prevalence of $S$. haematobium infection in 1998/1999 ranged from $10.2 \%$ to $26.4 \%$ in inland villages and from $21.0 \%$ to $72.7 \%$ in lakeshore villages; for school children prevalence of infection ranged from $15.3 \%$ to $57.1 \%$ in inland schools and from $56.2 \%$ to $94.0 \%$ in lakeshore schools (see Madsen et al., in press). Inhabitants on the islands, Chizumulu and Likoma, also had lower prevalence of infection than those living in lakeshore villages on Nankumba Peninsula. This increased prevalence in lake shore villages is not necessarily linked to transmission taking place in the lake itself, but could also be due to the presence of more numerous typical transmission (back waters and inland sites such as streams, ponds) being close to the lake. Re-infection after treatment of school children in some villages, Chembe and Chimphamba) on Nankumba Peninsula is as high as $40 \%$ using parasitological examination, but using more sensitive serological tests reinfection rates are considerably higher $(70 \%)$ (Madsen et al., in press).

\subsection{Schistosome transmission}

Two snail species are involved in transmission on the Nankumba Peninsula, i.e. B. globosus and B. nyassanus. Bulinus globosus (Morelet, 1866) is found in most of the sub-Saharan Africa in various freshwater habitats including streams, rivers, seasonal pools, and lakes (Brown, 1994; Mandahl-Barth, 1972; Cantrell, 1981; Madsen et al., 1987; Ndifon \& Ukoli, 1989). Bulinus nyassanus (Smith, 1877) is a member of the B. truncatus/tropicus group and is endemic to Lake Malawii; it is found on open sandy areas and has a preference for habitats devoid of vegetation and with substratum consisting of coarse and, to a smaller extent, fine sand, where it is normally found in the upper $2-3 \mathrm{~cm}$ of the substratum (Wright et al., 1967; Phiri et al., 2001; Madsen et al., 2004). Its status as intermediate host was not recognized prior to these studies (Madsen et al., 2001) and an alternative explanation for the changed transmission pattern was that another strain of S. haematobium, capable of using B. nyassanus as host, had been introduced on Nankumba Peninsula. Molecular data, however, do not suggest existence of two $S$. haematobium strains and $S$. haematobium from Likoma Island can infect B. nyassanus from Nankumba (Stauffer et al., 2008).

Transmission in the lake takes place both in back waters and in the lake proper and also in further inland habitats. Transmission in inland sites and back waters is through B. globosus and starts towards the end of the rainy season or early dry season in March/April and continues until sites dry; which could be as early as June/ July or 1-2 months later (Madsen et al., in press). A few sites may, however, persist for longer but B. globosus populations often disappear before sites dry. Usually several of such sites exist in village areas at the lake shore and these clearly contribute to the higher infection levels in lake shore communities. Many of these inland water bodies (Fig. 4) are actually streams that after rains become isolated from the lake (Madsen et al., 2004). Inland transmission can be found throughout 
the lake's upland. Especially, in the northern part of the lake such sites may be kept under water due to wave action. Some of the inland sites may support Biomphalaria pfeifferi and $S$. mansoni transmission (Fig. 5).
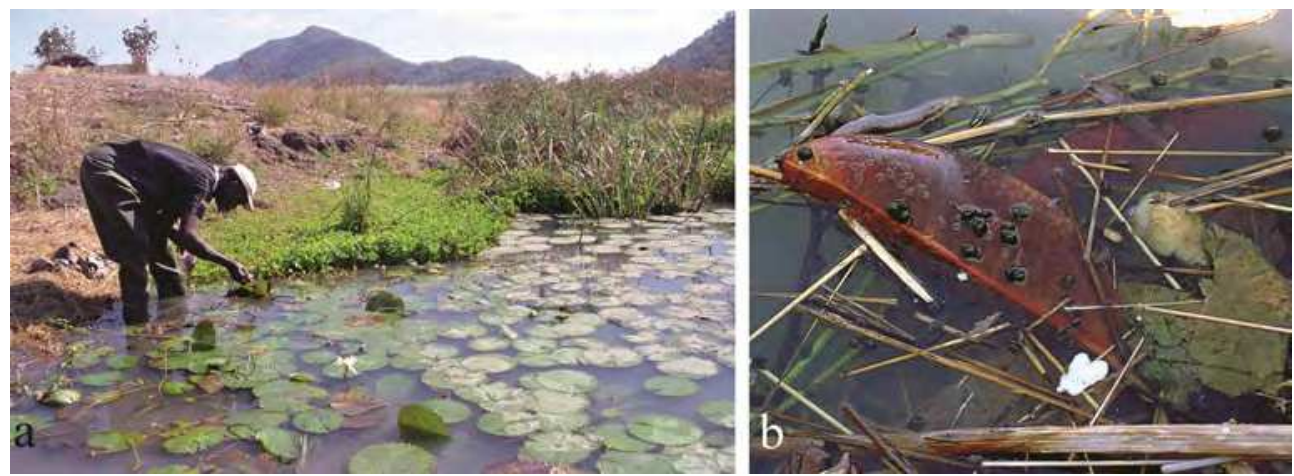

Fig. 4. Typical inland transmission site (a) with high density of Bulinus globosus (b).
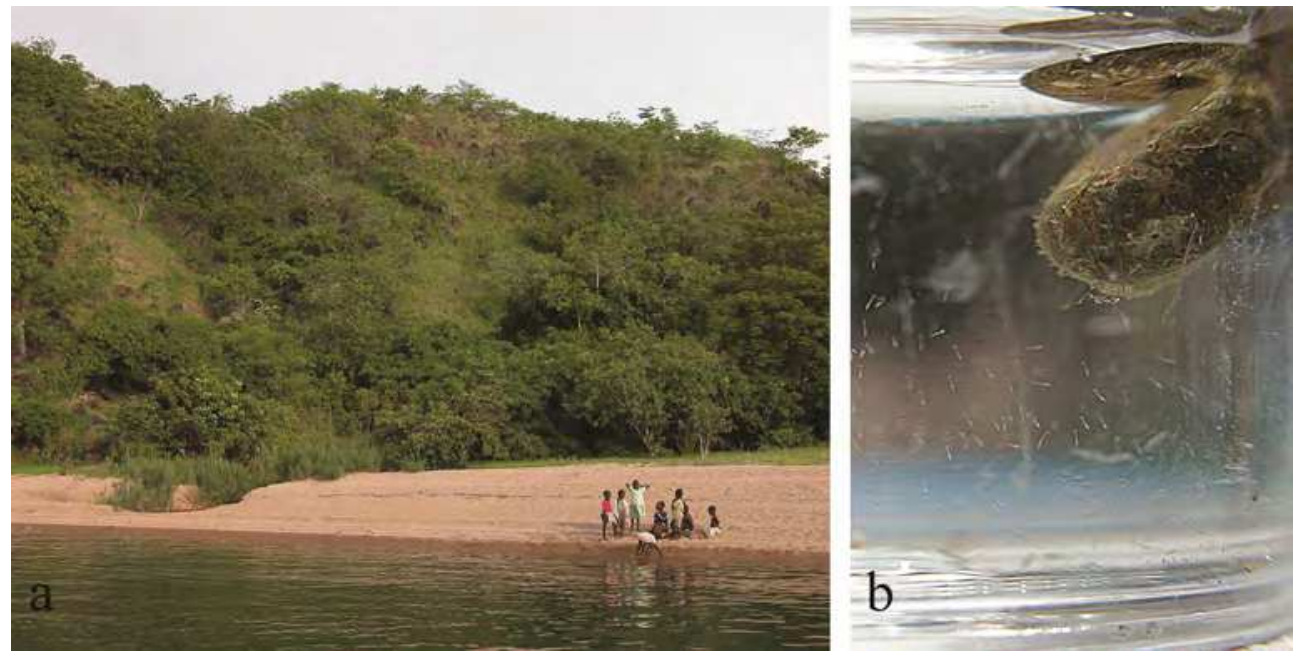

Fig. 5. A "stream" site (a) along the foothill harbouring Biomphalaria pfeifferi that shed cercariae of Schistosoma mansoni (b).

Transmission in the lake can be either by B. globosus along protected shorelines often with aquatic vegetation or presence of boulders in the water (Fig. 6) and/or through B. nyassanus along open sandy shorelines (Fig. 7) on the Nankumba peninsula (Madsen et al., 2004).

Transmission by B. globosus within the lake or backwaters may commence towards the end of the rainy season or shortly after and may continue through October/November which is much longer than transmission in sites further inland (Madsen et al., in press). Transmission through B. nyassanus will start May/July when populations increase in shallow water and persist into November/December depending on weather conditions, i.e. storms coming 


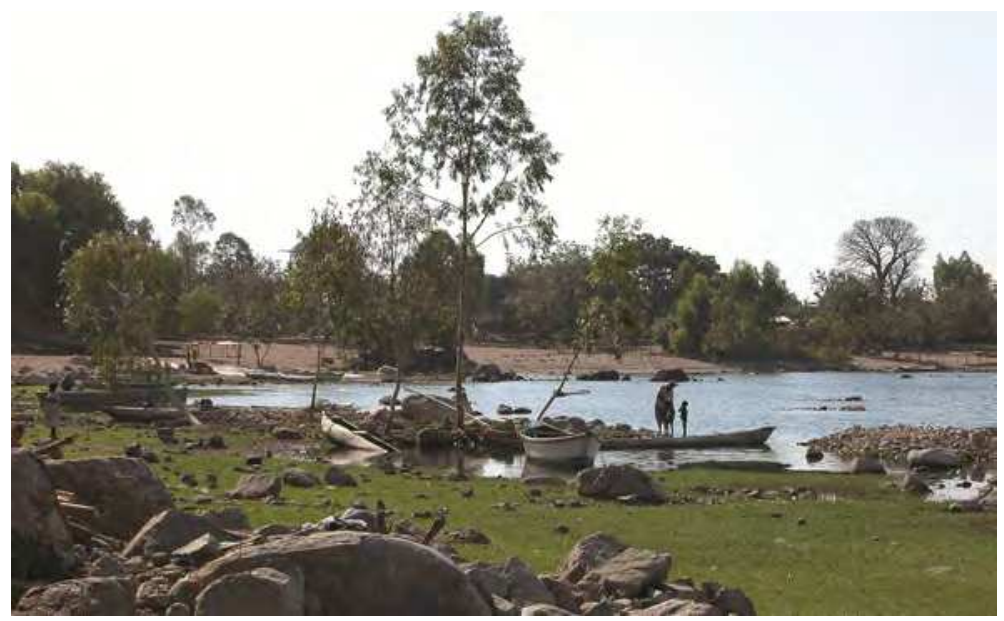

Fig. 6. Protected harbour site at Same Bay with transmission through Bulinus globosus.
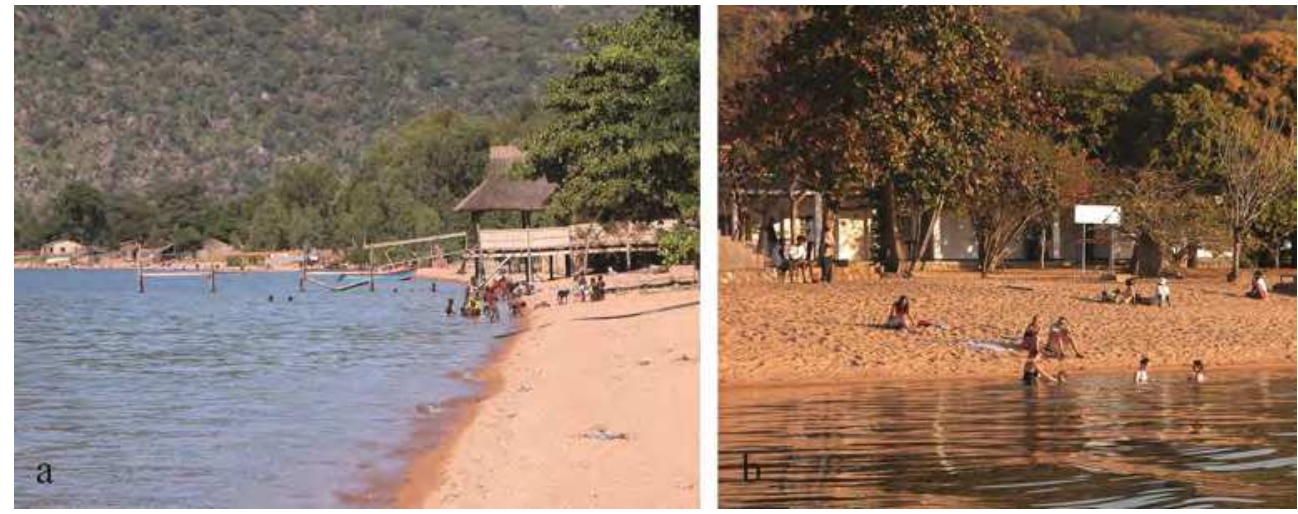

Fig. 7. Open beach at Chembe (a) where transmission of Schistosoma haematobium occurs with Bulinus nyassanus as intermediate host. This is the shoreline where many tourists (b) get infected.

from a northerly direction which can cause high mortality in B. nyassanus populations (Madsen et al., in press). Schistosoma haematobium transmission through B. nyassanus is limited to sites where snail occurs in shallow water close to shore. Infected $B$. nyassanus have been found only on Nankumba Peninsula. Density of B. nyassanus is generally higher in the southern part, especially in shallow water, of the Lake (Nankumba and Matola) than in the northern part. Density of $B$. nyassanus is partly governed by sediment composition (Genner \& Michel, 2003; Madsen \& Stauffer, in press) and further there is a negative association between density of B. nyassanus and density of T. placodon (Madsen \& Stauffer, in press).

\section{Snail fauna}

Lake Malawi has an impressive snail fauna (Fig. 8), though the snail fauna is less diverse than Lake Tanganyika's (Brown, 1994). For many years, the molluscs of Lake Malawi i 
continued to be known almost entirely from empty shells (Crowley et al., 1964). Later, collections of living specimens allowed substantial revision (Mandahl-Barth, 1972, Wright et al., 1967). A total of 28 gastropod species is recognized to live within the lake and on the swampy parts of its shores (Brown, 1994) of which 16 are endemic. Amongst these are the medically important species.

The prosobranch gastropods are dominated by Melanoides spp. (Oliver, 1804). Their shell is medium to large (max shell height $27 \mathrm{~mm}$ ), slender and dextral. It is the most abundant snail genus in Lake Malawi and distinction between species is an ongoing debate (Eldblom \& Kristensen, 2003; Sørensen et al., 2005). Gabbiella stanleyi (Smith, 1877) is a small (max size: $5.3 \mathrm{~mm}$ ) snail with a thick-walled dextral shell and is endemic to Lake Malawi (Brown, 1994). Four species of Lanistes (Montfort, 1810) are found in Lake Malawii; they have a sinistral shell with a max height of $75 \mathrm{~mm}$. Lanistes nyassanus (Dohrn, 1865) and L. solidus (Smith, 1877) are both endemic to Lake Malawi and found in shallow water and most common on sand among weedbeds (Louda et al., 1984; Brown, 1994). Several species Bellamya are known from Lake Malawî.

\subsection{Bulinus globosus}

Bulinus globosus (Morelet, 1866) belongs to the Bulinus africanus group and reaches a maximum of $22.5 \mathrm{~mm}$ in shell height (Brown, 1994). The globose shell has a blunted spire. Bulinus globosus is found in sub-Saharan Africa in various freshwater habitats including streams, rivers, seasonal pools, and lakes (Mandahl-Barth, 1972; Cantrell, 1981, Madsen et al., 1987, Ndifon \& Ukoli, 1989). The snail lives in shallow water, where it may occur on bare substrata, but is more common among aquatic plants (Thomas \& Tait, 1984). Bulinus globosus may be flushed into Lake Malawi during the rainy season, when lagoons and ponds adjacent to the lake overflow or are captured by the rising lake (Phiri et al., 2001). Bulinus globosus has been reported at several sites in Lake Malawii, especially in sheltered corners and near inflowing streams (Fryer, 1959; Madsen et al., 2004).

Bulinus globosus is the most widespread and probably the most important intermediate host for Schistosoma haematobium in Tropical Africa (Brown, 1994) and was until recently the only confirmed intermediate host for Schistosoma haematobium in Malawî (Teesdale et al., 1986, Brown, 1994, Msukwa \& Ribbink, 1997). Stauffer et al. (1997) and Msukwa \& Ribbink (1997) suggested that other Bulinus species, apart from Bulinus globosus, may also act as intermediate host for S. haematobium.

\subsection{Bulinus nyassanus}

Bulinus nyassanus (Smith, 1877) is a member of the B. truncatus/tropicus group and has a more thick-walled shell with a more pointed apex (barely projecting above the last whorl) compared to B. globosus. The maximum shell height of B. nyassanus is $13.6 \mathrm{~mm}$ (Brown, 1994). Bulinus nyassanus is endemic to Lake Malawi and is found on open sandy areas and has a preference for habitats devoid of vegetation and with substratum consisting of coarse and, to a smaller extent, fine sand, where it is normally found in the upper $2-3 \mathrm{~cm}$ of the substratum (Wright et al., 1967; Louda et al., 1983; Phiri et al., 2001; Madsen et al., 2004). Bulinus succinoides (Smith, 1877) is in the same group as B. nyassanus but smaller (maximum size: $6 \mathrm{~mm}$ ), more slender, and with a thinner shell living upon Vallisneria plants (Wright et al., 1967; Brown 1994). 


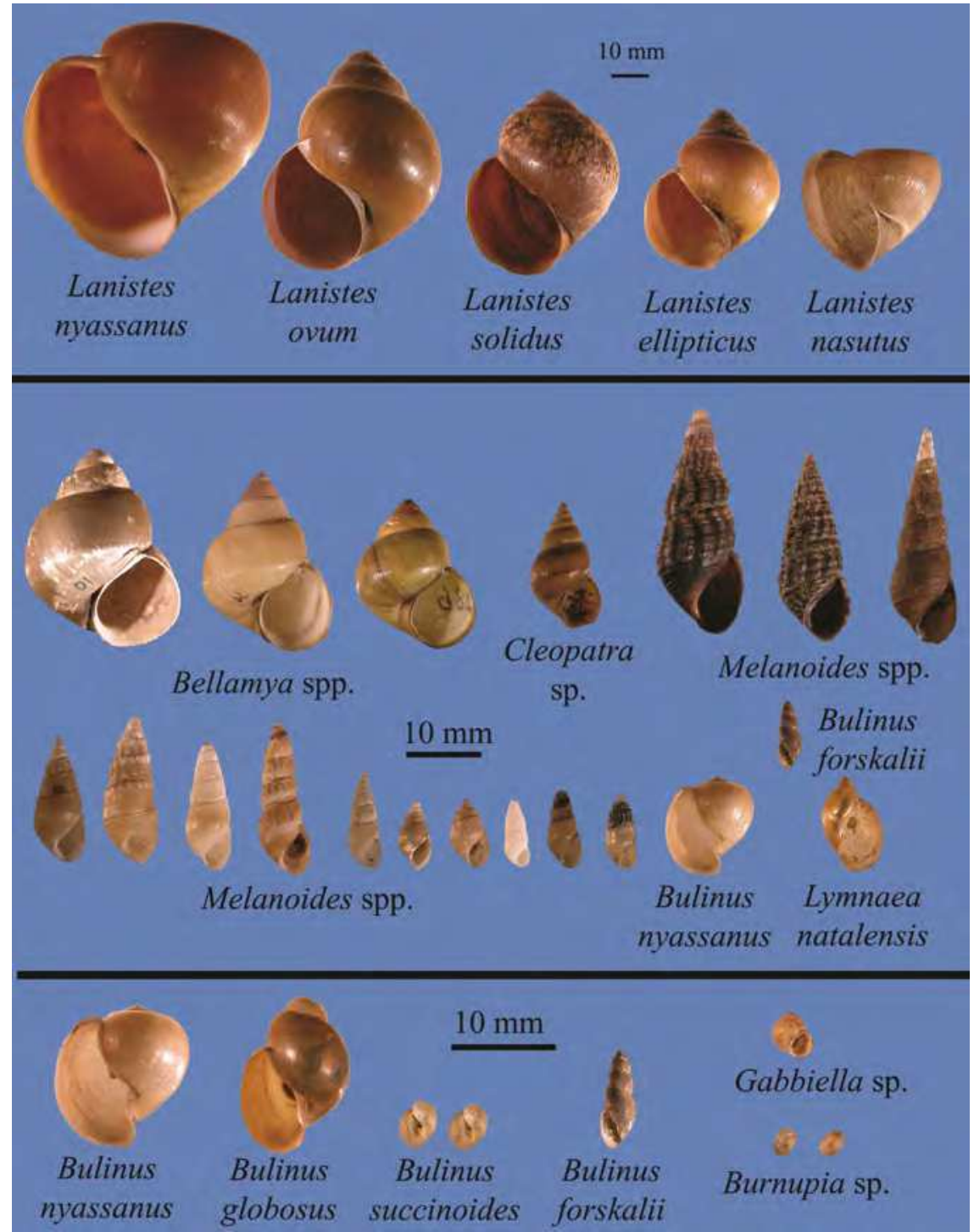

Fig. 8. Snail shells from Lake Malaŵi.

\subsection{Biomphalaria pfeifferi}

This genus comprises most of the larger planorbid snails in Africa and with a few exceptions these are of medical importance as intermediate hosts of Schistosoma mansoni (Danish Bilharziasis Laboratory, 1977). Eleven species are known from Africa and four of these are found in South-east Africa. The shell is discoid of medium size up 12-15 mm in diameter. Both in size and shell shape Biomphalaria pfeifferi (Fig. 9) is very variable and many local forms have been described as distinct species, but it is impossible to regard them even as 
subspecies. It is common throughout tropical Africa and the most important intermediate host of S. mansoni. In South-east Africa it is widely distributed, but rare or absent in the coastal area and in the great lakes.

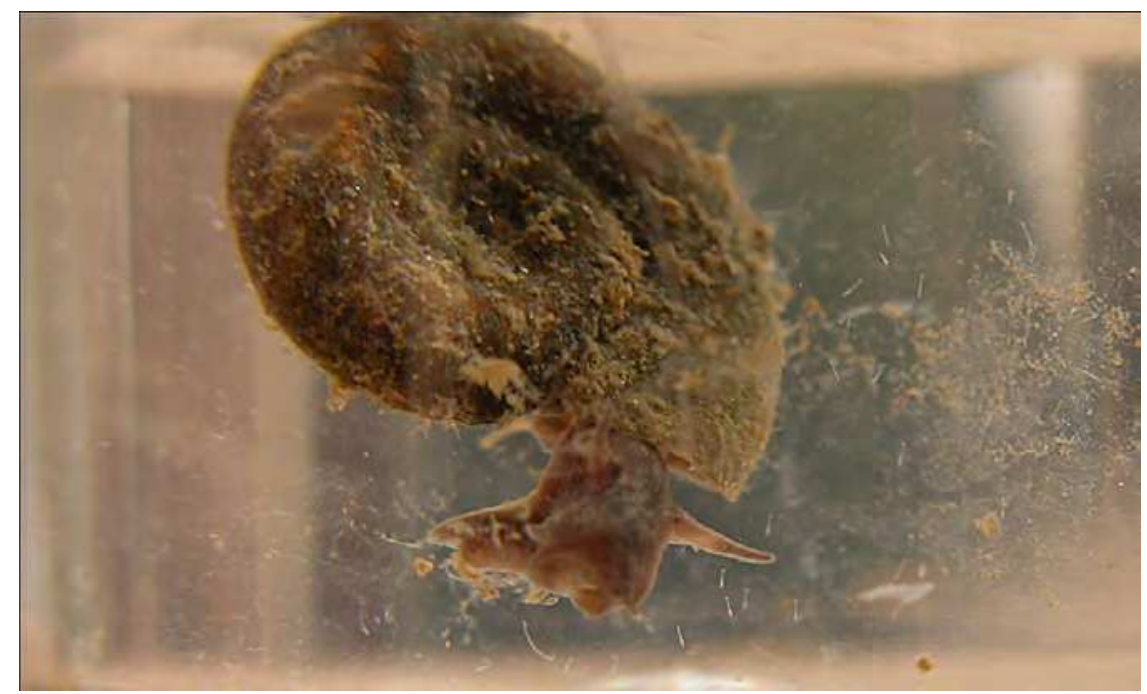

Fig. 9. Biompalaria pfeifferi

\section{Fish and fishing in Lake Malaŵi}

Lake Malawi harbors the most diverse ichthyofauna of any freshwater lake in the world, with as many as 850 species occurring (Konings, 2001). Lake Malawi cichlids exhibit spectacular diversity in trophic morphology, including specialist algal scrapers, planktivores, insectivores, piscivores, paedophages, snail crushers, and fin biters (Stauffer et al., 1995).

The rich fauna of this lake is primarily attributable to the explosive adaptive radiation and speciation of the haplochromine cichlids (Regan, 1922; Trewavas, 1935; Greenwood, 1979). As early as 1893, the diversity of the fishes inhabiting Lake Malawi i was recognized by Günther (Eccles \&Trewavas, 1989). Regan's (1922) revision of the fishes of Lake Malawi encouraged several collecting expeditions, which provided the material for Trewavas' (1935) classic synopsis of the fauna. The cichlids of Lake Malawi are characterized, in part, by both their inter- and intra-lake endemicity. The status of many of the groups described as genera, however, remain questionable as precise locality information is lacking for 32 of the 38 type species used to define these genera. In some cases, the validity of the type species of the genus is questioned. For example, the type species of Ctenopharynx is Ctenopharynx intermedius (Günther), and the type collection of C. intermedius consists only of the holotype, which is a relaxed skin with broken fins (Eccles \& Trewavas, 1989). Surveys have been undertaken of the cichlids in Lake Malawi (Ribbink et al., 1983; Lewis et al., 1986; Konings, 1990; Turner 1996), and, although these surveys resulted in new facts and speculation of the different forms, they did not result in comprehensive and formal descriptions of new taxa. The rapid speciation within these fishes has resulted in a paucity of characters needed to 
distinguish among taxa. This dearth of information about unique characters is at odds with the need to be able to delimit species for the conservation and utilization of these fishes for food, tourism, disease control, and scientific investigations. Certainly, there is an inherent obligation for all the species in a World Heritage Site, such as Lake Malawie to be documented and recognized.

\subsection{Diversity of Lake Malawi cichlids}

Cichlids are one of the most speciose families of vertebrates, with conservative estimates quoting more than 2000 extant species. Although native to tropical areas of the world, with the exception of Australia, some $70-80 \%$ of cichlids are found in Africa, with the greatest diversity found in the Great Lakes (lakes Victoria, Tanganyika, and Malawi). Their highly integrated pharyngeal jaw apparatus permits cichlids to transport and process food; thus enabling the mandibular jaws to develop specializations for acquiring a variety of food items. This distinct feature has allowed cichlids to achieve great trophic diversity, which in turn has lead to great species diversity.

By far, the greatest radiation of cichlids is found in the Great Lakes of Africa, with Lake Malawi alone having as many as 850 species. The phylogenetic diversity ranges from the single invasion of Lake Malawii, which resulted in the endemism of all but a few species, to multiple invasions in Lake Tanganyika, which resulted in the presence of 12 different tribes. The rich fauna of these lakes is primarily attributable to the explosive adaptive radiation and speciation of the pseudocrenilabrine cichlids. The driving mechanism for these speciation events is unknown. The two most widely proposed methods are allopatric speciation and intrinsic isolating mechanisms. Furthermore, biologists generally agree that female mate choice can act as a strong driving force in runaway speciation where the average female preference for a specific male trait differs between two allopatric populations. Thus, behavioral traits are important tools for the diagnosis of these African cichlids, primarily because behavioral traits played a very important role in and facilitated the rapid radiation of these fishes, which may not always be accompanied by discernable morphological changes. The importance of behavioral traits in delimiting the many species of Lake Malawi cichlids necessitates the use of SCUBA gear to document and record unique behaviors of the species being studied. In many cases, unique species can only be discerned by recording their different behaviors.

The driving mechanisms for the speciation events that led to the explosive radiation of the haplochromine cichlids in Lake Malawi is undiscovered; the two most widely proposed methods are allopatric speciation (Fryer \& Iles, 1972) and intrinsic isolating mechanisms. Several authors (Lande, 1981, West-Eberhard, 1983) proposed that rapid divergence of mate recognition via sexual selection could promote behavioral isolation and facilitate speciation. Runaway sexual selection has been proposed to partially explain rapid radiation of these fishes and Deutsch (1997) provided evidence that sexual selection may be associated with the color diversification of the Lake Malawi rock-dwelling cichlids.

\subsection{Fisheries in Lake Malaŵi}

The traditional fishing methods on Lake Malawi consisted of traps and beach seines operated from dugout canoes and small plank boats (Cohen et al., 1996). Fishing was originally artisanal using small craft, open water seines (chirimila), and gillnets. The fisheries consisted of Oreochromis spp. (chambo), the catfishes especially Bagrus meridionalis, 
the small pelagic cyprinid Engraulicypris sardella and small zooplanktivorous cichlid species (utaka). Labeo mesops was the most important riverine fishery and was originally second only to the chambo fishery. Ringnets were introduced in 1943, initially for catching Oreochromis species, and later to catch small pelagic species such as E. sardella (usipa) and small, zooplanktivorous haplochromine cichlids (utaka) (Ogutu-Ohwayo et al., 1997). The cyprinid L. mesops which was the most important riverine species was, as in the case of the Lake Victoria L. victorianus (Ogutu-Ohwayo, 1990), depleted due to intensive gillnetting of gravid individuals on breeding migrations (Cohen et al., 1996).

The first fishery survey of Lake Malawi showed that the main commercial fisheries were supported by cichlid tilapia caught in shore seines and open water ringnets. Since then however, tilapia abundances have declined and the species of endemic tilapia are now so scarce that the main commercial fishery (Maldeco, which works in association for the Malawi fisheries department) has resorted to breeding tilapia in fish farm ponds to stock large enclosures fixed in open waters in the south east arm of the lake (Lowe-McConnell, 2009). Here they rear endemic tilapia Oreochromis shiranus (Lowe-McConnell, 2009).

Research into environmental conditions affecting fish production in Lake Malawi has included, for example, the work by Duponchelle et al. (2005) on food partitioning within the species-rich benthic fish community. Using a combination of stable isotopes and stomach analysis, they found that, although benthic algal production contributed to the energy requirement of offshore fishes living in water 10-30 m deep, the larvae of the abundant lake fly Chaoborus edulis were the most important food source for demersal fishes; thus supporting the hypothesis that demersal fish production in Lake Malawi is sustained mainly through the pelagic food chain, rather than from benthic detritus.

Systematic overfishing of fresh waters is largely unrecognized because of weak reporting and because fishery declines take place within a complex of other pressures (Allan et al., 2005). Indeed, one of the symptoms of intense fishing in inland waters is the collapse of particular stocks even as overall fish production rises--a biodiversity crisis more than a fisheries crisis (Allan et al., 2005).

The annual trawl catch for the entire lake has fluctuated between 1000 and 3000 tonnes over the last 40 years. The small-scale fisheries exploit an estimated 110 species, with 25 species comprising $80 \%$ of the total catch by weight (FAO, 1993; Turner, 1995; Turner et al., 1995; Weyl et al., 2005). There is, however cause for caution as surveys in southern Lake Malawi have shown considerable overlap between artisanal and trawl fisheries (Weyl et al., 2005) and there is evidence that the artisanal gill net fishery is now operating at depths greater than $50 \mathrm{~m}$ (Weyl et al., 2005).

In addition, degradation of the spawning grounds due to excessive siltation following deforestation and de-vegetation of the catchment area may have affected L. mesops (Cohen et al., 1996). An industrial trawl fishery which was introduced on Lake Malawi during the 1970's to harvest small cichlids (Turner, 1977), accelerated the decline in stocks of certain species in the lake. The size and the number of cichlid species caught was reduced by $20 \%$ in some parts of the lake.

\subsection{Molluscivores}

Several molluscivorous fish species exist in Lake Malawi and of these, Trematocranus placodon (Regan, 1922) is the most abundant and widely distributed (Fig. 10) and it has been considered the potentially most active biological control agent for schistosomiasis (Chiota et 


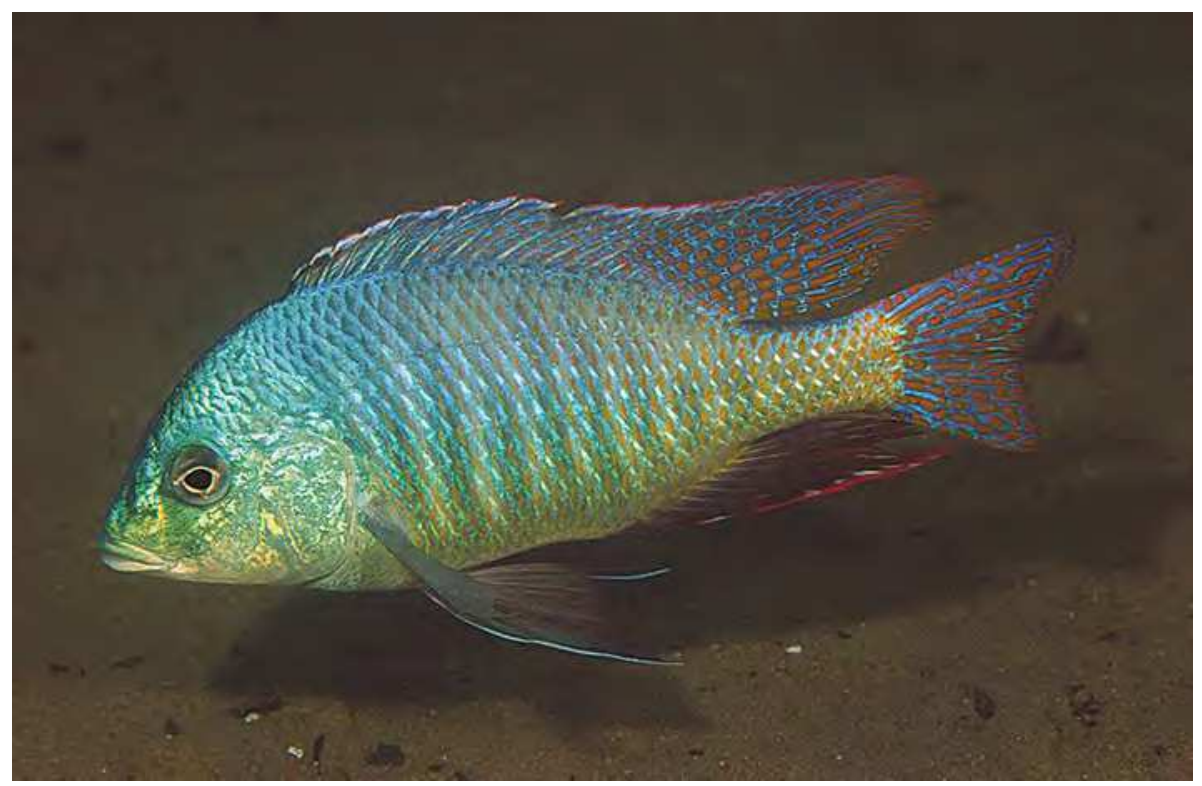

Fig. 10. Trematocranus placodon (Photo by Dr. Adrianus Konings).

al., 1991a,b; Msukwa \& Ribbink, 1997). Since then, experiments have been conducted to understand its foraging behavior and impact on snail distribution in natural and seminatural environments (Chiota et al., 1991a; Msukwa \& Ribbink, 1997). Trematocranus placodon has earlier been described as Haplochromis placodon, Cyrtocara placodon and Lethrinops placodon (Regan, 1922;Fryer \& Iles, 1972; Axelrod \& Burgess 1979; Slootweg, 1994). Trematocranus placodon is placed in the endemic "Hap" species flock, compared to the endemic Malawiian rock fishes or the "mbuna" flock (Fryer \& Iles, 1972). The cichlid is widespread throughout the lake (Axelrod \& Burgess, 1979) and it has three black spots on a silvery body and reaches a maximum total length of $23 \mathrm{~cm}$ (Konings, 2001). It is common in shallow waters on sandy bottoms where it forages mainly on gastropods. It exhibits sexual dimorphism during the breeding season from July to September, where the ripe male assumes a blue color, probably caused by hormones causing the chromatophores to expand (Fryer \& Iles, 1972; Konings, 2001). Trematocranus placodon has a very well developed pharyngeal jaw apparatus including upper and lower pharyngeal bones and ingested snails are moved to the pharynx where they are crushed (Fryer \& Iles, 1972). During the breeding season, the males are territorial, constructing bowers, which function as spawning sites. The females are mouth brooding (Konings, 2001). Trematocranus placodon possibly forage in groups, relying on group members to locate food (Chiota et al., 1991a); it feeds on benthic insects, detritus and fish scales before reaching maturity (at about $10 \mathrm{~cm}$ ) where it almost exclusively feed on bivalves and gastropods (Msukwa \& Ribbink, 1997). Trematocranus placodon locates snails in the sediment by their movements. When T. placodon detects a movement in the sediment via its enlarged pores on its chin, it attacks.

The molluscivorus fishes are particularly vulnerable to the artesian fishing gear when they are spawning or in shallow areas. We attribute the observed decrease in density of Trematocranus placodon, which is one of the most widespread snail-eating fish species, from 
1980 to 2003 to overfishing and the increased use of fine-meshed beach seines that collect juvenile fishes. During the 1970s and early 1980s most fishing activity took place in offshore waters. As these fishing stocks became depleted, fishermen moved inshore with illegal finemeshed nets. As these fishing pressures built, people started using beach seines and the fish in water less than $7 \mathrm{~m}$ were removed. The peak abundance of T. placodon then shifted to deeper waters where they were not susceptible to beach seines. We therefore concluded that we must encourage people from Chembe Village to consider a fish ban during certain times of the year in an effort to restore T. placodon to it former population levels in the shallow waters of Lake Malawii.

Trematocranus placodon feeds in preference on B. nyassanus although Melanoides species dominate in its stomach content. The proportion of large $(>4 \mathrm{~mm}) B$. nyassanus of all $B$. nyassanus consumed increased with fish size (Evers et al. 2006). Bulinus nyassanus seems to constitute a more profitable prey than Melanoides when evaluated on the basis of organic material gained relative to effort invested in shell crushing (Evers et al., 2011).

Our data suggest a negative relationship between density of T. placodon and density of $B$. nyassanus, and of Melanoides spp., while there is a positive relationship between densities of the two snail species (Madsen \& Stauffer, in press). Both snail species are the major elements in the diet of T. placodon and B. nyassanus appears to be the preferred species (Evers et al., 2006) especially during times of this snail's highest abundance in the field (Madsen et al., 2010).

\section{Controlling B. nyassanus through protection of fishes at village areas}

From the data, it is likely that prior to the mid 1980's, density of B nyassanus was kept low due to predation by $T$. placodon, i.e. biological control at work. Whether the changed distribution pattern of $T$. placodon is entirely the result of overfishing should be evaluated by following changes in fish and snail distribution after implementation of a fish-ban. Changes in fish populations may occur rapidly; when fish population density is high, beach-seining is attractive to the local people but after a period of intense beach seining fish population density will drop to levels where beach seining is no longer attractive. Subsequently, when beach seining is reduced fish populations will recover.

Because of the observed trend, we are optimistic about reversing the situation through an effective fish ban in village areas. Whether this would be sufficient to also reduce schistosome transmission remains to be seen. The intermediate host, B. nyassanus, undergoes marked seasonal variation in density in the very shallow water (i.e. water depth less than about $1.5 \mathrm{~m}$ ) close to the shore. Each year in December-January, B. nyassanus is virtually eliminated from these depths at Chembe Village and possibly other shore lines with a northerly exposure owing to wave action. During this period, B. nyassanus populations, however, persist in deeper water, where the density fluctuations are much less pronounced than in the shallows. Populations of B. nyassanus in the shallow water will then increase again close to the shore as the prevailing wind direction shifts from a northerly to a southerly direction. At present, snails in the very shallow water close to the shore appear not to be vulnerable to predation from T. placodon, but if T. placodon could return to forage in shallow water through implementation of a fish ban, as in 1978 (Stauffer et al., 1997), the annual increase of $B$. nyassanus in shallow water might be prevented, because it must be recruited from snails living in slightly deeper waters. Certainly, this was the situation in the late 1970s, when the open waters of Lake Malawi were regarded as schistosome free.

It is interesting that also for Melanoides density there is a significant inverse relationship with density of T. placodon. Evers et al. (2006) showed that although T. placodon preferentially 
feeds on B. nyassanus, the major component in its stomach content is actually Melanoides due to its dominance in the snail fauna ( $94 \%-96 \%$ as opposed to the 3-5\% for B. nyassanus). Evers et al. (2006) also showed that the maximum size (shell height) of Melanoides consumed by T. placodon of up to $230 \mathrm{~mm}$ (standard length) was about $15 \mathrm{~mm}$. Larger T. placodon probably would be able to handle slightly larger snails, but it is likely that the largest Melanoides specimens are not susceptible to predation by T. placodon. Another interesting observation is that density of $B$. nyassanus is positively related to density of Melanoides, contrary to the prediction of Genner et al. (2004).

The only realistic possibility for reducing density of $B$. nyassanus and thereby hopefully $S$. haematobium transmission is to protect populations of T. placodon in the near-shore areas of the lake. Although the use of fish for biological control of freshwater snails has failed in some areas (Slootweg et al. 1994, Slootweg 1995), this should not happen in the case of T. placodon in Lake Malawi, because nothing really changes i.e. the food availability for the fishes does not change and due to interactions with other fish species that are also protected we would expect its feeding repertoire to remain unaltered. Attempts should be made through government extension workers to introduce a community enforced shallow water fishing ban. We assisted in forming a committee at Chembe that should be promoting such a fish-ban by educating community members on the need for practicing sustainable use of fish resources. The committee engaged local leaders, villagers as well as fishermen on the need for implementing a community enforced fish ban in the period during which fish should be allowed to breed. Initially the committee worked well but at the end of the project, there was evidence that it was no longer effective. Thus, there has been no estimation of fish population density after implementation of the fish ban.

\section{Controlling B. globosus in back waters and inland sites}

Even if T. placodon can control B. nyassanus and transmission along open shorelines, $S$. haematobium transmission will persist in inland habitats and other measures will have to be implemented in those areas. Many villages have several inland sites where B. globosus can exist - e.g., often streams that during the dry season turn into a series of ponds. Several of the inland sites may contain water through the dry season almost until the following rainy season, while many others just contain water for a few months into the dry season. Beach seining probably constitutes an important source of protein for local people and, if banned, many people may not afford to purchase fish from fishermen who catch outside the fish ban zone. We therefore think that, possibilities of utilizing these inland sites for aquaculture should be explored. Although aquaculture have well documented positive effects (e.g., improved nutrition, better food security, better job opportunities and financial benefits), there are also concerns that such activities may lead to increased transmission of various water related diseases because installations (canals and ponds) often function as excellent habitats for intermediate hosts of trematodes (notably schistosomes and liver flukes). Furthermore, cultured species should be from the local watershed due to the high risk of escape to the lake. Fish ponds would probably be organically loaded and this might favor proliferation of the intermediate host snails, i.e. Bulinus globosus and possibly Biomphalaria pfeifferi. Aquaculture using polyculture including molluscivore species might not control the intermediate host snails although Chiotha et al. (1991a, b) have demonstrated that a mix culture that included T. placodon significantly reduced intermediate hosts. Experience from Cameroon and elsewhere was not promising because soft food items might be abundant in 
inland waters and molluscivores might shift to such food items and this can lead to reduction in the crushing mill reduing their ability to crush snails. Slootweg et al. (1993) even warns against aquaculture in schistosomiasis endemic areas. It may be necessary to control access to the fish ponds such that they do not become transmission sites even if they sustain dense populations of intermediate host snails.

\section{Conclusion}

Fishes from Lake Malawi comprise most of the animal protein consumed by Malawians, thus fishing pressure on inshore fishes is intense. We attribute the observed decrease in density of T. placodon from 1980 to 2003 in the shallow waters to overfishing and the increased use of seine-meshed beach seines. It is obvious that the peak abundance of $T$. placodon has shifted to deeper waters when compared to observations in earlier years (Stauffer et al., 1997; Stauffer et al., 2006). Furthermore, as density of snail-eating fishes decreased the density of the intermediate host, B. nyassanus, increased.

There is no doubt, that $B$. nyassanus is a major player in the transmission of urinary schistosomes in Lake Malawi. In those areas where both B. globosus and B. nyassanus are intermediate hosts, the prevalence of infection in school-aged children is 2-3 times higher than where only B. globosus is a host (Stauffer et al., 2006; Stauffer et al. 2008). Relative to B. nyassanus, we found: (1) Schistosoma haematobium transmission through B. nyassanus is limited to sites where it occurs in shallow water close to shore; (2) Infected B. nyassanus have been found only on Nankumba Peninsula; (3) Density of B. nyassanus is generally higher in the southern part of the Lake (Nankumba and Matola) than in the northern part; and (4) Density of $B$. nyassanus is partly governed by sediment composition, i.e. particularly a high content of the clay fraction is a negative predictor.

Based on the above, we initially postulated that a different strain of $S$. haematobium was introduced into Lake Malawi that was preadapted to infect B. nyassanus. Bulinus nyassanus is a diploid member of the Bulinus truncatus/tropicus group. Most members of this group that are intermediate hosts are tetraploid, thus it was surprising that $B$. nyassanus was a player in transmission of urinary schistosomes in Lake Malawî. Stauffer et al. (2008) reported that the schistosomes found in B. globosus and B. nyassanus could not be genetically differentiated. Furthermore, they demonstrated that miracidia shed from children that originated from $B$. globosus could infect B. nyassanus. Thus, Stauffer et al. (2008) suggested that $S$. haematobium in Lake Malawi always had the potential to infect both B. globosus and B. nyassanus.

Finally, we concluded that if reductions in prevalence of schistosome infections in people are achieved through chemotherapy campaigns, we will need to protect native fish populations in near shore areas of the lake. The question is whether an effective prevention of fishing within a $100 \mathrm{~m}$ zone from the shore will restore fish populations and will this lead to reduced density of $B$. nyassanus, especially in the shallow waters. We have shown that a fish ban can be established and implemented, but it will require continued support from extension workers in the village. In order to reduce fishing pressure in the lake, we should consider creating alternative sources of fish protein and thereby reduce dependence on the natural fish populations.

\section{Acknowledgment}

We thank the government of Malawi for giving us permission to work in Lake Malawi ind the University of Malawi for providing us with the proper permits to collect fishes and 
snails. For the parasitological studies on people, we would like to express our gratitude to the National Health Sciences Research Committee of the Ministry of Health for ethical clearance of the studies. We also thank the District Health Officers in the Mangochi and Likoma districts for their involvement and assistance in the implementation of the research. The work was conducted in collaboration with Malawîi Fisheries Department and Malawi Parks and Wildlife Department. We are grateful for the help provided by Dr. Adrianus Konings and all our staff. Funding was provided by the NSF/NIH joint program in ecology of infectious diseases (DEB-0224958).

\section{References}

Allan, J. D.; Abell, R.; Hogan, Z.; Revenga, C.; Taylor, B. W.; Welcomme, R.L. \& Winemiller, K. (2005). Overfishing of inland waters. BioScience, 55, 1041-1051

Axelrod, H.R. \&Burgess, W.R. (1979). African Cichlids of Lakes Malawîi and Tanganyika. 8th Edition. Tropical Fish Hobbyist Publications. Neptune, New Jersey

Beadle, L.C. (1974). The inland waters of Tropical Africa. An introduction to tropical limnology. Logham Group Ltd. 365 pp.

Brown, D.S. (1994). Freshwater Snails of Africa and Their Medical Importance. 2nd Edition. Taylor and Francis, London.

Cantrell, M. A. (1981). Bilharzia snails and water level fluctuations in a tropical swamp. Oikos, 36, 226-232

Centers for Disease Control. (2005). Health information for travelers to East Africa. Available: www.cdc.gov/travel/eafrica.gtm [accessed 12 May, 2005]

Chiotha, S.S.; McKaye, K.R. \& Stauffer, J.R. (1991a). Prey handling in Trematocranus placodon, a snail-eating cichlid fish from Malawi. Ichthyological Exploration of Freshwater, 2, 203-208

Chiotha, S.S.; McKaye, K.R. \& Stauffer, J.R. (1991b). Use of indigenous fishes to control schistosome snail vectors in Malawîi, Africa. Biological Control, 1, 316-319

Cohen, A., Kaufman, L., \& Oguto-Ohwayo, R. (1996). Anthropogenic threats, impacts, and conservation stragegies in the African Great Lakes - A review. In: The Limnology, Climatology, and Paleoclimatology of the East African Lakes (Editors: Johnson, T. \& Odada, E.) Gordon \& Breach Publishers, Newark, New Jersey, 575-624

Crowley, T. E., Pain, T. \& Woodward, F.R. (1964). A monographic review of the Mollusca of Lake Nyasa. Annales de la Musée royal de l'Afrique Centrale: Sciences Zoologiques, 131, 1-58

Danish Bilharziasis Laboratory (1977). A field guide to identification of African freshwater snails. 4: South East African species. Danish Bilharziasis Laboratory

Deutsch, J.C. (1997). Colour diversification in Malawi cichlids: evidence for adaptation, reinforcement, or sexual selection? Biological Journal of the Linnean Society, 62,1-14

Duponchelle, F.; Ribbink, A. J.; Msukwa, A.; Mafuka, J.; Madere, D. \& Bootsma, H. (2005). Food partitioning within the species-rich benthic fish community of Lake Malawii, East Africa. Canadian Journal of Fisheries and Aquatic Sciences, 62, 1651-1664

Eccles, D.H. \& Trewavas, E. (1989). Malawivian cichlid fishes: The classification of some haplochromine genera. Lake Fish Movies, Herten, West Germany

Eldblom, C. \& Kristensen, T.K. (2003). A revision of the genus Melanoides (Gastropoda: Thiaridae) in Lake Malawii. African Zoology, 38, 357-369 
Evans, A.C. (1975). Report on visit to Malâîi, 19th-31st May 1975: Investigations into schistosomiasis potential in and around lake-shore resorts and other tourist sites, with suggestions and recommendations. Report to Ministry of Trade, Industry, and Tourism

Evers, B.N. ; Madsen, H.; McKaye, K.R. \& Stauffer, J.R., Jr. (2006). The schistosome intermediate host, Bulinus nyassanus, is a preferred food for the cichlid fish, Trematocranus placodon, at Cape Maclear, Lake Malawivi. Annals of Tropical Medicine, $100,75-85$

Evers, B.N.; Madsen, H. \& Stauffer, J.R., Jr. (2011). Crush-resistance of soft-sediment gastropods of Lake Malawi: Implications for prey selection by molluscivorous fishes. Journal of Freshwater Ecology, 26, 85-90

Food and Agriculture Organization. (1993). Fisheries management in south-east Lake Malawii, the Upper Shire River and Lake Malombe. CIFA Technical Paper 17. 106 pp. FAO, Rome

Fryer, G. (1959). The trophic interrelationships and ecology of some littoral communities of Lake Nyasa with especial reference to the fishes, and a discussion of the evolution of a group of rock-frequenting Cichlidae. Proceedings of the Zoological Society of London, 132, 153-281

Fryer, G. \& Iles, T. D. (1972). The Cichlid Fishes of the Great Lakes of Africa. Tropical Fish Hobbyist Publications. Neptune, New Jersey

Genner, M.J. \& Michel, E. (2003). Fine-scale habitat associations of soft-sediment gastropods at Cape Maclear, Lake Malaŵi. Journal of Molluscan Studies, 69, 325-328

Genner, M.J.; Michel, E.; Erpenbeck, D.; De Voogd, N.; Witte, F. \& Pointier, J.-P. (2004). Camouflaged invasion of Lake Malawi by an Oriental gastropod. Molecular Ecology, 13, 2135-2141

Greenwood, P.H. (1979). Towards a phyletic classification of the 'genus' Haplochromis (Pisces: Cichlidae) and related taxa. Part 1. Bulletin of the British Museum (Natural History) Zoology, 35, 265-322

Konings A. F. (1990). Book of Cichlids and All Other Fishes of Lake Malawîi. Tropical Fish Hobbyists Publications. Neptune, New Jersey

Konings, A. F. (2001). Malâ̂i cichlids in their natural habitat. (3 $3^{\text {rd }}$ edition). Cichlid Press. El Paso. USA.

Lande, R. (1981). Models of speciation by sexual selection on polygenic traits. Proceedings of the National Academy of Sciences, 78, 3721-3725

Lewis, D.; Reinthal, P. \& Tremdall, J. (1986). A Guide to the Fishes of Lake Malawii National Park. World Conservations Centre. Gland, Switzerland

Louda, S.M.; Gray, W.N.; McKaye, K.R. \& Mhone, O.J. (1983). Distribution of gastropod genera over a vertical depth gradient at Cape Maclear, Lake Malawii. The Veliger, 25, 387-392.

Louda, S.M.; McKaye, K.R.; Kocher, T.D. \& Stackhouse, C.J. (1984). Activity, density and size of Lanistes nyassanus and L. solidus (Gastropoda, Ampullaridae) over the depth gradient at Cape Maclear, Lake Malawii, Africa. The Veliger, 25, 145-152

Lowe-McConnell, R. (2009). Fisheries and Cichlid Evolution in the African Great Lakes: Progress and Problems. Freshwater Reviews, 2, 131-151

Madsen, H.; Bloch, P.; Kristensen, T.K. \& Furu. P. (2001). Bulinus nyassanus is intermediate host for Schistosoma haematobium in Lake Malawii. Annals of Tropical Medicine and Hygiene, 95, 353-360 
Madsen, H.; Bloch, P.; Makaula, P.; Phiri, H.; Furu, P. \& Stauffer, J.R. Jr. (in press). Schistosomiasis in Lake Malawi i villages. EcoHealth

Madsen, H.; Coulibaly, G. \& Furu, P. (1987). Distribution of freshwater snails in the river Niger basin in Mali with special reference to the intermediate hosts of schistosomes. Hydrobiologia, 146, 77-88

Madsen, H. \& Stauffer, J.R. Jr. (in press). Density of Trematocranus placodon (Pisces: Cichlidae): A predictor of density of the schistosome intermediate host, Bulinus nyassanus (Gastropoda: Planorbidae), in Lake Malawi. EcoHealth

Madsen, H.; Stauffer, J.R., Jr.; Bloch, P.; Konings, A.; McKaye, K.R. \& Likongwe, J.S. (2004). Schistosomiasis transmission in Lake Malawii. African Journal of Aquatic Science, 29, 117-119

Madsen, H., Kamanga, K.C.J., Stauffer, J.R. Jr. \& Likongwe, J. (2010). Biology of the molluscivorous fish Trematocranus placodon (Pisces: Cichlidae) from Lake Malawii. Joumal of Freshwater Ecology, 25, 449-454

Mandahl-Barth, G. (1972). The freshwater mollusca of Lake Malawii. Revue de zoologie et de botanique Africaines, 86, 257-289

Msukwa, A.V. \& Ribbink, A.J. (1997). The potential role of sanctuary areas for biological control of schistosomiasis in Lake Malawî national park. In: Proceedings of "Workshop on Medical Malacology in Africa", Harare, Zimbabwe, Sep. $22-26$ (Eds. Madsen, H., Appleton C.C. \& Chimbari, M.) p.305- 317

Ndifon, G.T. \& Ukoli, F.M.A. (1989). Ecology of freshwater snails in south-western Nigeria. I: Distribution and habitat preferences. Hydrobiologia, 171, 231-253

Ogutu- Ohwayo, R. (1990). The decline of the native fishes of Lakes Victoria and Kyhoga (East Africa) and the impact of introduced species, especially the Nile perch, Lates niloticus and Nile tilapia, Oreochromis niloticus. Environmental Biology of Fishes, 27, 81-96

Ogutu- Ohwayo, R.; Hecky, R.E.; Cohen, A.S. \& Kaufman, L. (1997). Human impacts of the African Great Lakes. Environmental Biology of Fishes, 50, 117-131

Phiri, H., Bloch, P. Madsen, H. \& Dudley, C. (2001). Distribution and population dynamics of Bulinus globosus and B. nyassanus on Nankumba Peninsula, Mangochi District, Malâ̂i. Preliminary findings. In: Proceedings of "Workshop on Medical and Veterinary Malacology in Africa", Harare, Zimbabwe, Nov. 8-12, (Eds. Madsen, H., Appleton C.C. \& Chimbari, M.) p. 273-286.

Regan, C.T. (1922). The cichlid fishes of Lake Nyassa. Proceedings of the Zoological Society of London, 1921, 675-727.

Ribbink, A.J.; Marsh, B.A.; Marsh, A.C.; Ribbink, A.C. \& Sharp, B.J. (1983). A preliminary survey of the cichlid fishes of rocky habitats in Lake Malawi. South African Journal of Zoology, 18, 149-310.

Slootweg, R. (1994). A multidisciplinary approach to schistosomiasis control in Northern Cameroon with special reference to the role of fish in snail control. ICG Printing Dortrech. DSc thesis. University of Leiden. The Netherlands

Slootweg, R. (1995). Snail control by fish: an explanation for its failure. NAGA, The ICLARM Quarterly, 16-19.

Slootweg, R.; Malek, E.A. \& McCullough, F.S. (1994). The biological control of snail intermediate hosts of schistosomiasis by fish. Reviews in Fish Biology and Fisheries, 4, 67-90 
Slootweg, R.; Vroeg, P. \& Wiersma, S. (1993). The effects of molluscivorous fish, water quality and pond management on the development of schistosomiasis vector snails in aquaculture ponds in North Cameroon. Aquaculture and Fisheries Management, 24, 123-128

Stauffer, J.R.; Arnegard, M.E.; Cetron, M.; Sullivan, J.J.; Chtsulo, L.A.; Turner, G.F.; Chiotha, S. \& McKaye, K.R. (1997). Controlling Vectors and hosts of parasitic diseases using fishes. A case history of schistosomiasis in Lake Malaŵi. BioScience, 47, 41-49

Stauffer, J. R., Jr.; Bowers, N.J.; McKaye, K.R. \& Kocher, T.D. (1995). Evolutionarily significant units among cichlid fishes: The role of behavioral studies. American Fisheries Society Symposium, 17, 227-244

Stauffer, J.R. Jr.; Madsen, H.; McKaye, K.; Konings, A.; Bloch, P.; Ferreri, C.P.; Likongwe, J. \& Makaula, P. (2006). Molluscivorous Fishes - Potential for Biological Control of Schistosomiasis. EcoHealth, 3, 22-27

Stauffer, J. R., Jr.; Madsen, H.; Konings, A.; Bloch, P.; Ferreri, C.P.; Likongwe, J.; Black, K. \& McKaye, K.R. (2007). Taxonomy: A precursor to understanding ecological interactions among schistosomes, snail hosts, and snail-eating fishes. Transactions of the American Fisheries Society, 136, 1136-1145

Stauffer, J. R., Jr.; Madsen, H.; Webster, B.; Black, K.; Rollinson, D. \&Konings A. (2008). Schistosoma haematobiumin Lake Malawi: snail hosts (Bulinus globosus, Bulinus nyassanus) susceptibility and molecular diversity. Journal of Helminthology,82, 377-382

Sørensen, L. V.G., Jorgensen, A. \& Kristensen, T. K. 2005. Molecular diversity and phylogenetic relationships of the gastropod genus Melanoides in Lake Malawii. African Zoology, 40, 179-191

Teesdale, C.H.; Choudhry, A.W.; Pugh, R.N.; Ellison, R.N. \& Alford, D.P. (1986). Bilharzia A manual for health workers in Malawîi National Bilharzia Control Programme. Ministry of Health, Malawi

Thomas, J.D. \& Tait, A.I. (1984). Control of the snail hosts of schistosomiasis by environmental manipulation: a field and laboratory appraisal in the Ibadan area, Nigeria. Philosophical Transactions of the Royal Society, London, B, 305, 201-254

Turner, G. F. (1995). Management, conservation and species changes of exploited fish stocks in Lake Malawi. In: The Impact of Species Changes in African Lakes. (Editors: Pitcher, T. J. \& Hart, P. J. B.) 365-397

Turner G.W.; Tweddle, D. \& Makwinja, R. D. (1995). Changes in demersal cichlid communities as a result of trawling in southern Lake Malawi. In: The Impact of Species Changes in AFrican Lakes (Editors: Pitcher, T. J. \& Hart, P. J. B.) 339-412

Turner, G.R. (1996). Offshore Cichlieds of Lake Malawîi. Cichlid Press, El Paso, Texas.

Turner, J.L. (1977). Some effects of demersal trawling in Lake Malaŵi (Lake Nyasa) from 1968 to 1974. Journal of Fish Biology, 10, 261-271

Trewavas, E. (1935). A synopsis of the cichlid fishes of Lake Nyassa. Annals and Magazine of Natural History, ser. 10, Vol.16, 65-118

West-Eberhard, M.J. (1983). Sexual selection, social competition, and speciation. Quarterly Review of Biology, 58, 155-183

Weyl, O.L.F.; Nyasula, T., \& Rusuwa, B. 2005). Assessment of catch, effort, and species changes in the pair trawl fishery of southern Lake Malawii, Malawiwi, Africa. Fisheries Management and Ecology, 12, 395-402 
World Health Organization (2002). Prevention and control of schistosomiasis and soil transmitted helminthiasis: Report of a WHO expert committee. World Health Organization, Technical Report Series 912

Wright, C.A., Klein, J. \& Eccles, D.H. (1967). Endemic species of Bulinus in Lake Malawii. Journal of Zoology, London, 151, 199-209 


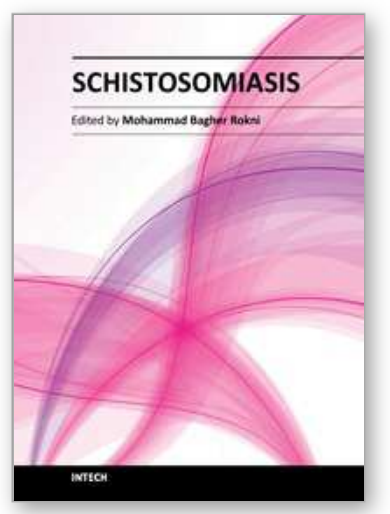

\author{
Schistosomiasis \\ Edited by Prof. Mohammad Bagher Rokni
}

ISBN 978-953-307-852-6

Hard cover, 310 pages

Publisher InTech

Published online 13, January, 2012

Published in print edition January, 2012

In the wake of the invitation by InTech, this book was written by a number of prominent researchers in the field. It is set to present a compendium of all necessary and up-to-date data to all who are interested. Schistosomiasis or blood fluke disease, also known as Bilharziasis, is a parasitic disease caused by helminths from a genus of trematodes entitled Schistosoma. It is a snail-borne trematode infection. The disease is among the Neglected Tropical Diseases, catalogued by the Global Plan to combat Neglected Tropical Diseases, 2008-2015 and is considered by the World Health Organization (WHO) to be the second most socioeconomically devastating parasitic disease, next to malaria. WHO demonstrates that schistosomiasis affects at least 200 million people worldwide, more than 700 million people live in endemic areas, and more than 200.000 deaths are reported annually. It leads to the loss of about 4.5 million disability-adjusted life years (DALYs).

\title{
How to reference
}

In order to correctly reference this scholarly work, feel free to copy and paste the following:

Jay R. Stauffer, Jr. and Henry Madsen (2012). Schistosomiasis in Lake Malawi and the Potential Use of Indigenous Fish for Biological Control, Schistosomiasis, Prof. Mohammad Bagher Rokni (Ed.), ISBN: 978-953307-852-6, InTech, Available from: http://www.intechopen.com/books/schistosomiasis/schistosomiasis-in-lakemalawi-and-the-potential-use-of-indigenous-fish-for-biological-control

\section{INTECH}

open science | open minds

\section{InTech Europe}

University Campus STeP Ri

Slavka Krautzeka 83/A

51000 Rijeka, Croatia

Phone: +385 (51) 770447

Fax: +385 (51) 686166

www.intechopen.com

\section{InTech China}

Unit 405, Office Block, Hotel Equatorial Shanghai

No.65, Yan An Road (West), Shanghai, 200040, China 中国上海市延安西路65号上海国际贵都大饭店办公楼405单元

Phone: +86-21-62489820

Fax: $+86-21-62489821$ 
(C) 2012 The Author(s). Licensee IntechOpen. This is an open access article distributed under the terms of the Creative Commons Attribution 3.0 License, which permits unrestricted use, distribution, and reproduction in any medium, provided the original work is properly cited. 